\title{
USE OF SOCIAL NETWORKS FOR THE TRAINING OF FUTURE TEACHERS IN EARLY CHILDHOOD EDUCATION
}

\author{
Mercedes Llorent-Vaquero, África M. Cámara-Estrella, Elena M. Díaz-Pareja, \\ \& Juana M. Ortega-Tudela \\ Department of Pedagogy, University of Jaen (Spain)
}

\begin{abstract}
Currently, social networks have a great potential in the educational field, being useful to promote motivation, the active role of students, communication or flexibility in time and space, among others. In this line, this paper shows an experience of educational innovation in higher education mediated by the use of social networks. Specifically, the social network Instagram was used with students in the second year of the Early Childhood Education Degree at the University of Jaen. The objective of this study was to analyze the impact of the use of social networks on aspects related to the quality of the educational process, such as motivation, creativity, communication or monitoring. In order to respond to the proposed objective, a quantitative methodology was used, with a descriptive method and a survey design. The data collection instrument was a student questionnaire through which the impact of the use of the social network Instagram in the teaching-learning process was evaluated. The results point to a positive effect of the use of social networks on the variables under study. It should be noted how the use of this social network has influenced the motivation towards their learning and the communication processes that were developed with all those involved.
\end{abstract}

Keywords: Social networks, Instagram, teachers training, early childhood education, higher education.

\section{Introduction}

Social networks have become a tool that encompasses many aspects of daily life, and education is one of them. As a social process, education can be enriched by the use of these networks to share, collaborate, exchange experiences, knowledge, resources, etc. (Mora, Signes, De Miguel \& Gilar, 2015).

The use of social networks in the classroom enables the transmission of knowledge and the inter-group collaboration. In this sense, they motivate the students to personal reflection and group work, fostering autonomous work (Buxarrais, 2016). They also facilitate the exchange of knowledge, while promoting the dissemination of learning in a faster and wider way (Mora, Signes, De Miguel \& Gilar, 2015).

The research on university teaching and social networks that we present has been developed around the idea that the use of the social network Instagram is a motivating and encouraging element of the active role of the student in the training process. In order to know the knowledge management capacity that the use of the social network Instagram brings to university students, we have adapted the educational practices of the students to the use of this social network. In this way, the objective is to know the benefits of the use of Instagram in the teaching-learning process.

As an educational tool and support for the dissemination of acquired professional skills (Pérez, 2015; Piscitelli, 2010), it is an open field of work for university teaching. Currently, the world of young people cannot be understood without knowing these socialization tools, and we cannot turn our backs on this reality. Moreover, as teachers, we need to approach social networks and turn them into methodological resources close to the students.

\section{Design}

This study describes the results of an innovative learning experience. This experience was carried out in the University of Jaen, specifically in the second year of the degree in Early Childhood Education. The subject in which the experience was developed was Educational Technology. In this sense, this 
academic year $(2020 / 21)$ the professors team of the subject decided to change the methodology in the development of the practices of the subject.

The purpose of these practices is to create multimedia materials for early childhood education students. For several years we used the Service Learning methodology in this process. We contact educational centers asking for their needs for multimedia materials. According to the teachers' needs we elaborate the multimedia materials and we deliver it to them, so it can be useful. The changes introduced this academic year was the use of Design Thinking in the design process of the multimedia materials and the use of the social network Instagram as a learning tool. Through Design Thinking we expected the development of the creativity of the student by using different techniques. Instagram was introduced as a learning tool thinking about the motivation that could be for the students and the possibilities that it has for communication and monitoring.

In the development of the project of creating multimedia materials, the students formed work groups. Each group has an Instagram account and they used this social network as a blog, creating an Instablog. They publish their project phases, step by step, sharing with their colleagues and trying to get some dissemination and interaction in this social network. It is worth mentioning the creativity they showed in the exhibition of their contents.

The professor has another account in which she was publishing information about the process, techniques, deadlines, etc. Also the professor used the account to encourage the students and give them support and inspiration.

\section{Objectives and methods}

This paper analyzes the assessment of the innovative learning experience described above, specifically in relation to the use of the social network Instagram. Thus, the objective of this study is to analyze the impact of the use of social networks on aspects related to the quality of the educational process, such as motivation, creativity, communication or monitoring. In order to respond to the proposed objective, a quantitative methodology was used, with a descriptive method and a survey design.

The data collection instrument was an ad-hoc student questionnaire, validated by experts, through which the impact of the use of the social network Instagram in the teaching-learning process was evaluated. This questionnaire was created online using Google Forms. It was composed of 38 items that analysed different dimensions. From all the dimensions, this study focuses on fourth of them because of their interest in relation with the assessment of the learning experience. These dimensions are: Motivation, Creativity, Communication and Monitoring.

A total of 61 students answered the questionnaire. Most of them were females $(88,5 \%)$ compared to a small percentage of men $(11,5 \%)$. Their ages ranged from 18 to 35 years old, with a mean value of 20,93 . Only a few percent were repeat students $(8,2 \%)$. And a high percentage $(63,9 \%)$ had never used social networks in the teaching-learning process before.

The results of this paper show the descriptive study carried out. The data analysis was accomplished using the SPSS statistical software in its 26 version.

\section{Results}

The results are presented according to the four dimensions of the study. First, the percentages achieved in each of the items that compose the dimensions are shown. Secondly, the averages of the dimensions are presented for comparison purposes.

Figure 1. Results of the motivation dimension.

Encouraged you to seek out and learn how to handle new applications and resources

Increased your motivation for the project

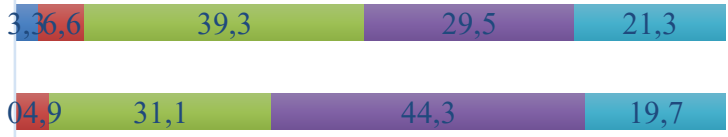

$\begin{array}{lllllllllll}0 & 10 & 20 & 30 & 40 & 50 & 60 & 70 & 80 & 90 & 100\end{array}$

- Mostly disagree $\quad$ Slightly disagree $\quad$ Slightly agree $\quad$ Mostly agree $\quad$ Completely agree 
Almost all the students agree (slightly, mostly or completely) with the statements related to the motivation. The use of Instagram as a learning tool has encouraged them to seek out and learn how to handle new applications and resources and also it has increased their motivation for the project.

Figure 2. Results of the creativity dimension.

\begin{tabular}{|c|c|c|c|c|c|c|}
\hline \multirow{6}{*}{$\begin{array}{r}100 \\
80 \\
60 \\
40 \\
20 \\
0\end{array}$} & 9.8 & & & & & \\
\hline & 27,9 & 36,1 & & & 26,2 & 45,9 \\
\hline & & 31,1 & & & 31,1 & \\
\hline & 52,5 & 23,0 & & & 36,1 & 27,9 \\
\hline & $\begin{array}{l}\text { It has favored your } \\
\text { reflection and critical } \\
\text { thinking }\end{array}$ & Improved your & creativity & $\begin{array}{r}\text { It has e } \\
\text { look } 1 \\
\text { diff }\end{array}$ & $\begin{array}{l}\text { ncouraged you to } \\
\text { or inspiration in } \\
\text { erent contexts }\end{array}$ & $\begin{array}{l}\text { It has made you want to } \\
\text { do something different } \\
\text { from the rest, being } \\
\text { original. }\end{array}$ \\
\hline & Mostly disagree & lightly disagree & Slightl & $y$ agree & Mostly agree & Completely agree \\
\hline
\end{tabular}

With respect to creativity, a few students slightly disagree with the idea that using Instagram has boosted their creativity. However, most of them consider that they have improved their creativity, their reflection and critical thinking, and the search for inspiration in different contexts. In addition, among all of them, they consider that this learning experience makes them want to do something different, being more original than usual.

Figure 3. Results of the communication dimension.

\begin{tabular}{|c|c|c|c|c|c|}
\hline \multirow[t]{3}{*}{$\begin{array}{r}40,0 \\
35,0 \\
30,0 \\
25,0 \\
20,0 \\
15,0 \\
10,0 \\
5,0 \\
0,0\end{array}$} & $\begin{array}{r}36, \mathrm{~B} 6,1 \\
23,0\end{array}$ & $26,2^{39,5}$ & $31,1^{34,4} 29,5$ & $\begin{array}{r}31,1,27,96,2 \\
14,8\end{array}$ & $\begin{array}{r}34,46,1 \\
24,6\end{array}$ \\
\hline & $\begin{array}{l}\text { It has favored the } \\
\text { closeness with your } \\
\text { teacher }\end{array}$ & $\begin{array}{l}\text { It has favored the } \\
\text { closeness with your } \\
\text { class-group }\end{array}$ & $\begin{array}{l}\text { It has imporved your } \\
\text { communication with } \\
\text { the teacher }\end{array}$ & $\begin{array}{l}\text { r It has facilitated the } \\
\text { exchange of } \\
\text { experiences with } \\
\text { other colleagues }\end{array}$ & $\begin{array}{l}\text { It has made it easier } \\
\text { for you to better } \\
\text { understand the steps } \\
\text { to be taken to } \\
\text { develop your project }\end{array}$ \\
\hline & Mostly disagree & - Slightly disagree & - Slightly agree & Mostly agree & Completely agree \\
\hline
\end{tabular}

Regarding the communication dimension, the results point out that most of the students think that the use of Instagram has improved the communication. Specially, they are convinced that it has favored closeness and communication with the professor, more than with the class-group or the colleagues. Nevertheless, most of them agree (slightly, mostly or completely) with all the items of this dimension.

Figure 4. Results of the monitoring dimension.

It has favored the teacher's monitoring of your progress in the project

It has improved the feedback from the teacher

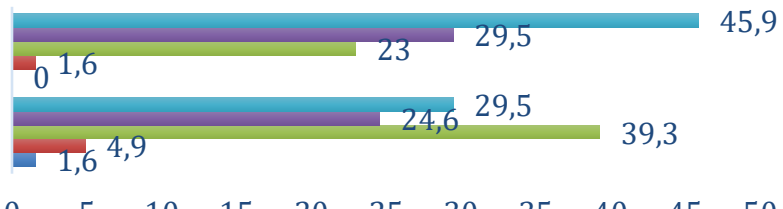

घompletely agree $\quad$ Mostly agree $\quad$ Slightly agree $\quad$ Slightly disagree $\quad$ Mostly disagree 
The fourth and last dimension analyze the monitoring of the learning experience. In this sense, most of the students completely or mostly agree with the statement that the use of Instagram improved de professor's monitoring of the projects. Also, they think it has favored the professor's feedback.

Likewise, when we analyze the mean values of each dimension, we realize that there are some differences between them. Motivation dimension is the lowest rated, although we can consider its value $(3,69)$ as a good assessment by the student, since the scale ranges from 1 to 5 . The dimensions Creativity $(3,8)$ and Communication $(3,81)$ are valued more than Motivation but less than Monitoring, that is the highest rated $(3,98)$.

\section{Discussion}

After analyzing the questionnaire answered by the students, the results affirm that, as concluded in other studies (Buxarrais, 2016), the attitude of students towards the educational use of social networks has been a success. This success is based on the promotion of cooperative learning, the creation of more flexible environments in terms of space and time, the increase of the students' protagonism in their own learning, the improvement of information exchange, the promotion of creativity and the generation of new contexts to work and interact.

However, we found that these facts contradict the research of Espuny, González and Leixà i Gisbert (2016), in which they manifested students' resistances towards the educational use of social networks.

Taking into account the existing concern about how the time dedicated to the use of social networks by young people takes time away from other activities (Sanmartín, Ballesteros, Calderón, \& Kuric, 2020), it is worth noting that these university students use them as tools for study, creation and knowledge management (Buxarrais, 2016). In this sense, they improve their creativity, looking for new sources of inspiration in contexts different from the merely educational ones, and they encourage motivation in the rest of their classmates to deepen their work and share it.

We understand that promoting the use of social networks in the university educational environment as a teaching resource is a necessity in the process of knowledge management and transformation of teaching-learning methodologies. Thus, through its use, the teaching-learning process becomes more active, motivating and shared.

\section{Conclusions}

The results point to a positive effect of the use of social networks on the variables under study. In general, the four dimensions analyzed obtain good valuations by the students. In this sense, we can state that the use of the social network Instagram as a learning tool has fostered motivation and creativity in students as well as improved communication and monitoring.

Among all dimensions, the monitoring was the most valued dimension, especially the monitoring of the progress in the projects made by the students. Also, it should be noted how the use of this social network has influenced the motivation towards their learning and the communication processes that were developed with all those involved.

The use of Instagram has led to improvements in the teaching-learning process during the development of this innovation experience.

\section{References}

Buxarrais, M.R. (2016). Redes sociales y educación. En La educación en la sociedad del conocimiento, 17 (2), 15-20. [Fecha de Consulta 9 de Marzo de 2021]. Disponible en Disponible en: http://www.redalyc.org/articulo.oa?id=535554762002

Espuny, C., González, J., Lleixà, Mar, \& Gisbert, M. (2011). Actitudes y expectativas del uso educativo de las redes sociales en los alumnos universitarios. En: «El impacto de las redes sociales en la enseñanza y el aprendizaje» [monográfico en línea]. Revista de Universidad y Sociedad del Conocimiento (RUSC). Vol. 8, n. ${ }^{\circ} 1$, págs. 171-185. UOC.

http://rusc.uoc.edu/ojs/index.php/rusc/article/view/v8n1-espuny-gonzalez-lleixa-gisbert/v8n1-espunygonzalez-lleixa-gisbert 
Mora Mora, H., Signes Pont, M. T., De Miguel Casado, G., \& Gilart Iglesias, V. (2015). Management of social networks in the educational process. En Computers in Human Behavior, 51, Part B, 890-895. doi:http://dx.doi.org/10.1016/j.chb.2014.11.010

Pérez, N. (2015). Facebook como plataforma de aprendizaje. Etic@net, 15(2), 395-402. DOI: https://doi.org/10.30827/eticanet.v15i2.11959

Piscitelli, A. (Coord.) (2010). El proyecto Facebook y la posuniversidad. Sistemas operativos sociales y entornos abiertos de aprendizaje. Barcelona/Madrid: Ariel/Fundación Telefónica. Disponible en http://www.codajic.org/sites/www.codajic.org/files/El\%20Proyecto\%20Facebook.pdf

Sanmartín, A., Ballesteros, J.C., Calderón, D. \& Kuric, S. (2020) De puertas adentro y de pantallas afuera. Jóvenes en confinamiento. Madrid. Centro Reina Sofía sobre Adolescencia y Juventud, Fad. DOI: $10.5281 /$ zenodo.4054836 